\title{
Competing Knowledge Systems in the Management of Fish and Forests in the Pacific Northwest
}

\author{
LESLIE KING \\ Dean, Faculty of Environment, University of Manitoba, Winnipeg, Manitoba, Canada R3T 2N2 \\ (E-mail: lking@cc.umanitoba.ca)
}

This paper is dedicated in loving memory to Virginia Walsh.

Accepted 17 December 2003

\begin{abstract}
In this paper I investigate the interaction of knowledge and institutions in the context of First Nations in the Pacific Northwest of Canada who have evolved management systems for fish and forest resources over hundreds of years. These management systems are viewed as institutions that are based on and apply knowledge systems over time. In the Nisga'a and Haida nations, knowledge systems guide management regimes that govern access, rights and responsibilities, harvesting, allocation of benefits and costs, technology, education and training. For the past hundred years these institutions and knowledge systems have come into conflict with knowledge and management systems imposed first by missionaries, settlers and colonizers and later from Provincial and National governments and corporations holding tenure rights assigned by those governments. National and international regimes such as the Law of the Seas and the Exclusive Economic Zones conflict with traditional institutions and knowledge systems by privileging one level of governance and consequently one form of knowledge and devaluing others. The paper is based on research conducted in the Pacific Northwest over the past eight years, primarily through interviews with elders, decisionmakers, and resource users, as well as observation of cultural and resource practices. The research investigated the impacts of conflicting knowledge systems and the attempts to resolve those conflicts. The paper raises questions about knowledge systems and institutions, about institutional interplay, and the impact of international institutions on local institutions as they come into contact and conflict.
\end{abstract}

Key words: co-management, first nations, fisheries, institutions, knowledge, pacific northwest, traditional ecological knowledge, TEK

\section{Introduction}

First Nations in the Pacific Northwest have evolved management systems for fish and forest resources over hundreds of years. These institutions are based on and apply knowledge systems that evolved over centuries (Calder 1993; Raunet 1996). Knowledge systems guide management regimes that govern access, rights and responsibilities, harvesting, allocation of benefits and costs, technology, education 
and training. They are also intricately related to governance, spirituality, and social relationships of the nation. For the past hundred years these institutions and knowledge systems have come into conflict with knowledge and management systems imposed first by missionaries, settlers and colonizers and later from Provincial and National governments and corporations holding tenure rights assigned by those governments. National and international fisheries regimes such as the Law of the Seas and the Exclusive Economic Zones (EEZs) conflict with traditional institutions and knowledge systems by privileging one level of governance and one form of knowledge and devaluing others. This paper addresses the impacts of that conflict and the attempts to resolve those conflicts, ranging from comanagement arrangements for the management of resources (Gwaii Haanas, Gitksan, Lava Beds, Nisga'a Fish and others), community-based forestry enterprises, (Tanizul, Teeslee) to self-government and the institutionalization of a knowledge system in a constitution (Wilp Si'ayuukhl Nisga'a/Nisga'a Lisims Government). Achieving self-government has been the impetus for comprehensive institution building or rebuilding and can be seen as a way of "taking back the commons" by aboriginal people in Canada. One of their greatest challenges is to rebuild institutions for resource and common property management that reflect their traditional values rather than succumb to the pressures of aligning their institutions with national and international regimes based upon knowledge systems of the dominant culture.

This paper raises questions about institutional interplay, and the impact of international and national institutions on local institutions as they come into contact and conflict. While those interactions often have negative consequences for local institutions, the paper asks what other consequences such interplay may have. For instance it is increasingly well known that institutions, their shape, design, and mechanisms are profoundly influenced by knowledge systems, and by shared beliefs and values of individuals and societies that create and operate within them. What might be the impact of institutions on knowledge systems and change in those systems? How might the interplay of institutions with highly different knowledge bases shape the knowledge and beliefs of the different actors, cultures and societies that created them? How does institutional interplay affect knowledge systems, particularly traditional knowledge systems? Do institutions privilege some forms of knowledge and knowledge systems over others? Does this restrict the range of options available to regimes to solve the problems they were designed to address? These questions are critical when considering the design, performance and impacts of international environmental agreements. In the context of First Nations in Northwestern Canada, I evaluate the impacts of institutional arrangements on knowledge systems and on the ecosystem/resources and assess implications for sustainability. In particular, I assess the significance of knowledge systems in sustainable environmental governance and the resilience of such knowledge systems under different institutional arrangements and in the face of global economic forces. 


\section{Knowledge and Institutions}

This paper explores the connection between knowledge and institutions through looking at the impacts of institutional interplay on institutions and knowledge systems. That "socially held beliefs are crucial determinants of patterns of governance" (Walsh 2000) would not come as a surprise to the Nisga'a Nation, inhabitants of their ancestral lands in the Nass Valley in Northwestern British Columbia, who in both the past and the present have deliberately attempted to incorporate traditional community values into rebuilding governance and social institutions. Research increasingly documents ways in which knowledge systems influence institutions. Do institutions also influence knowledge systems by privileging some forms of knowledge while devaluing others and perhaps causing their loss - at least to decision, policy-making and environmental problem solving? Young proposes "institutions as determinants of the growth of knowledge" (Young 2002). Could they also be determinants of the restriction or loss of knowledge? This may well be the case if an institution privileges one knowledge system over another (sometimes by privileging one level of governance over others). It is through the interplay of institutions that knowledge systems come into conflict. The vertical interplay of institutions at the global and national level with local institutions designed to govern the same resource has often resulted in the destruction of those local institutions with negative impacts on the sustainability of the resource in question.

\subsection{Conflicting Institutions and Knowledge Systems}

Many First Nations people see the operation of institutional forces beyond their control, as the cause of many of their environmental ills, and not as a source of solutions. Examples include the contamination of subsistence food resources in aboriginal communities and long-range pollution by industry. Across Canada many such examples abound, including the presence of Aluminium in Akwesasne cows, causing them to sicken and die, the contamination of groundwater sources of drinking water on the reservation with a toxic soup from a containment pond outside the General Motors foundry, and mercury levels in fish in James Bay reservoirs as a result of the hydro-electric developments in the region (unpublished observations). People heavily dependent on such resources are much more exposed and disproportionately suffer the health consequences. Communities are caught in a terrible bind-either renounce their traditional life styles and lose their culture, or suffer the often drastic health consequences of consumption of contaminated subsistence resources. Inevitably both consequences are felt in many aboriginal communities (Shkilnyk, 1985).

Another example is British Columbian fisheries, where the Dominion government of Canada began managing fisheries in the newly minted province from the late 19th Century. In creating a fisheries management regime where, they thought, none had previously existed, they created new "rules of the game" to govern fisheries access, 
harvesting and technology. But First Nations already had their own "rules of the game" when the colonists, settlers, and later, Federal and Provincial governments started to play the game with their own rules, and imposed those new rules on the old players. The resulting conflict was a conflict of knowledge systems and institutions based on that knowledge. Inevitably, the local institutions were undermined and in many cases, destroyed and fisheries went into the decline that they have experienced up to the present. Recently, some First Nations have been reclaiming those institutions and attempting to become partners in national and international regimes through a struggle to establish their rights to natural resources.

In Canada today, the land claims process is a mechanism for First Nations to develop land tenure and environmental regimes as a way of healing both their ecosystems and their communities and empowering them to create sustainable communities. They hope to reverse the process of loss of land base, leading to ecosystem stress and loss of traditional livelihoods, loss of culture and resulting breakdown of community and health to develop indigenous institutions that integrate ecological, economic, social, cultural, and health concerns (Nyce et al. personal communication). First Nations concepts of health already incorporate harmony with the natural world, balance, and community. These communities are therefore instructive in ways that we can integrate concepts of ecosystem and community health. The Tl'azt'en of Northern British Columbia have attempted to build resource-based enterprises as a way of restoring community and economic viability. They have obtained a Tree Farm License and have been operating wood products (Teeslee) and logging (Tanizul Timber) ventures. The elders have insisted on sustainable practices such as stream buffers, no use of herbicides and pesticides, limited, sustainable cutting regimes and priority on youth employment within the community. These practices are already running afoul of Provincial stumpage rates, revealing the difficulties of unilaterally preserving ecosystems at the local level. The much heralded Nisga'a Treaty has been anticipated by the community for many years, and the Nisga'a of the Nass Valley in Northern British Columbia have already initiated a variety of sustainable resource-based enterprises that build on traditional practice and knowledge, such as fisheries management using fish wheels for stock assessment and monitoring as well as recent practices for which youth in the Community have been trained. Since the historic signing of the Nisga'a Agreement, the Nisga'a have developed institutions that integrate social, economic, and ecological goals and needs of the community. In spite of these hopeful signs, many communities lose their battles and only recently have these local actions become part of a broader movement for recognition of traditional rights to resources that has the potential to influence policy and lead to more widespread attempts to ensure environmental justice, and the preservation of traditional knowledge and institutions.

In this paper, I document ways in which the Nisga'a Nation and other nations of the Pacific Northwest have addressed the challenges of conflicting institutions and knowledge systems. The Nisga'a Nation evolved institutions over centuries, such as the "wilp" or house system, the common bowl (Saytk'ilhl Wo'osim) (symbolic of 
resource sharing among house members and the nation) and feasting to govern access, property rights, harvesting systems, technologies, and distribution of benefits as well as stewardship of the entire territory or ecosystem for future generations. When these institutions came into conflict with the evolving Dominion fisheries regime, a variety of mechanisms served to undermine those institutions, such as making the traditional technology of fishing (weirs, nets, traps) illegal in the Barricade Act of 1905, discriminatory licensing of fishers, and more generally, banning the potlatch (1885) which pushed the traditional governance system to the brink of destruction. With self-government the Nisga'a are now succeeding in "Nisga'anizing" their fishery and in reasserting their rights and knowledge systems into partnership arrangements with Federal fisheries institutions. I return to the Nisga'a story later in the paper. The loss of traditional knowledge and institutions is seen by many as a great tragedy and as a barrier to the effective implementation of global environmental regimes (Berger and Nyce personal communications, Notzke 1994).

\subsection{KNOWLedge Systems}

Social and environmental scientists have increasingly become interested in traditional ecological knowledge (TEK) and the ways in which traditional knowledge can be integrated with western scientific knowledge to contribute to environmental solutions on a broad scale (Brush and Stabinsky 1996; Berkes 1999; Battiste 2000). Perhaps one of the most hotly debated issues of global as well as local environmental justice is the issue of competing knowledge systems, the devaluing but also usurping of indigenous, traditional and local ecological knowledge, including issues of intellectual property rights, and what has come to be known as "biopiracy". It has been documented that in the conflict among knowledge systems, the science, technology and cosmology of first world cultures or "western science", often dominates and subjugates other knowledge systems. International regimes designed to solve global and regional environmental problems increasingly rest on mechanisms for incorporating scientific assessments, usually quantitative data generated by academics and technicians, into policy and compliance instruments. Thus by their nature, they tend to favour western science over the knowledge of local and traditional resource managers, harvesters and consumers. Several scholars attempt to identify the importance of studying and preserving indigenous and traditional ecological knowledge and its conservation. Balick and Cox, in their text on ethnobotany, express the difficulty, urgency and significance of their field:

“ ...the loss of indigenous knowledge systems is accelerating throughout the world... As traditional peoples become increasingly Westernized, much of the richness of their traditions disappears. Plant lore that is passed down to only selected member of a community appears to be particularly susceptible to such cultural erosion ... the worldwide loss of plant biodiversity is accelerating as well. Knowledge of the uses of plants from threatened habitats appears to be especially vulnerable to loss" (Balick and Cox 1997, p. 23). 
These statements point to some of the issues and consequences of dismissing or disadvantaging indigenous and traditional ecological knowledge. One response is the tendency for scientists attempting to "integrate" western science with traditional ecological knowledge, to abstract the knowledge from the culture and attempt to classify, codify, record, and use that knowledge (for instance in research on climate change) without reference, and often without credit, to the culture from whence it came. This practice and the actions of pharmaceutical companies among others to extract TEK for profit, has in part, led to the movement for intellectual property rights as a means of compensating the holders of the knowledge. It has been argued however, that using the market to create a market in intellectual property rights, instead of protecting traditional ecological knowledge and compensating the holders, will rather devalue the knowledge by commoditizing it and making it even easier to exploit.

Some scholars suggest other, non-market ways of protecting indigenous knowledge, including "indigenous heritage rights and legal remedies, but these approaches all share the principle that traditional ecological knowledge can be communicated or shared but never "alienated" or sold (Posey and Dutfield 1996; Battiste and Henderson 2000). Another problem raised by the appropriation of traditional ecological knowledge is the notion that "pieces" of TEK can be extracted from a body of knowledge of a people.

"In searching for alternative solutions for global issues, there is always the risk of abstracting traditional knowledge from its cultural and historical context... Traditional ecological knowledge may best be seen as an integrated package that includes the local knowledge and classification systems of the groups in question; their environmental practices and management systems, if any; their social institutions that provide the rules for management systems such as tribal territories; and their worldviews that constitute the ideological or ethical basis of those systems" (Berkes 1999, pp. 23-24).

Exploitation of TEK may turn out to be worse than the indifference and neglect that until very recently characterised the attitude of western scientists to traditional knowledge. These issues provide a caution to those who advocate simple solutions to institutional and knowledge system conflicts. One solution often proposed to bridge the gulf in knowledge systems and avoid the negative consequences of institutional conflict is co-management.

\section{Co-Management}

Co-management, also known as cooperative, collaborative or shared resource management, has been on the one hand hailed as the solution to injecting traditional ecological knowledge into environmental policy making and on the other as "cooptive" management which tokenizes and trivializes traditional knowledge. Berkes (1991) defined co-management as the sharing of power and responsibility between government and resource users. Osherenko (1988) expands the definition of co- 
management as an institutional arrangement covering a specific geographical area where local users and the state agree to a system of reciprocal rights and obligations, a collection of rules indicating actions to be undertaken in different circumstances, and procedures and processes for collective decision-making. Co-management is based on the premise that conservation and management are more effective when they include the participation of local interests (Western 1989; Western and Wright 1994; Borrini-Feyerabend 2000; Warren 1998). Advocates claim that co-management will promote stewardship and sustainability, integrate aboriginal and government knowledge and management approaches, gain greater participation and community buy-in and support and improve the effectiveness of environmental regimes (Berkes 1989, 1994; Pinkerton 1989; Singleton 1998). Several researchers have evaluated the results of various co-management initiatives with First Nations and report varying degrees of success (Osherenko 1988; Notzke 1994; Campbell 1996). Some have recently suggested that the ambitious goals of co-management such as power sharing and integration of knowledge systems as well as long-term goals of ecosystem sustainability, may be difficult to achieve in practice (Berkes 1991; Nakashima 1991; Pinkerton and Weinstein 1995; Beckley 1998; Prystupa 1998). Over the past several years, Canadian policy and regulations have encouraged and required consultation with First Nations and participation of First Nations in decision-making and environmental management. For example, the Haida recently won a judgment against a large logging company for their failure to consult adequately with the Haida Nation on their logging practices and plans. Aboriginal groups now have a seat at the table in a wide variety of environmental management discussions including fisheries, forestry, wildlife management, water management, land use planning and parks and protected areas.

Although co-management appears to have the potential to blend or integrate different ways of knowing in environmental management that promise has largely not been met. Several researchers have identified barriers to effective co-management as a means of preserving traditional knowledge and incorporating it into effective policy and management (Pinkerton 1999; Berkes 1989). These include failure to address power imbalances and cultural differences, and promote meaningful power sharing, communications problems, sole reliance on government institutions for research support, environmental assessments without adequate time frames and resources to accommodate traditional knowledge research and documentation and meaningful participation of aboriginal people. They also include the inability of government education systems to provide the opportunity for students to understand a different way of knowing and the absence of aboriginal jurisdiction over education, health care, justice, land and resources (Pinkerton 1999). International trade agreements are also cited as potentially limiting local economic opportunities or land and resource control for aboriginal peoples. As we shall see later in this paper the Nisga'a Nation has addressed most, if not all of these concerns in their governance institutions and in their co-management arrangements. Since co-management has been so often posed as the solution to preserving traditional knowledge and 
integrating it with western scientific knowledge in environmental management regimes, it is important to consider ways in which such institutional arrangements can combat these barriers. In the following sections, I shall use fisheries as an example both of the ways in which national and international institutions have undermined traditional knowledge and institutions and some of the ways in which attempts have been made to combat that trend.

\section{Historical Perspective: Fisheries Regimes in the Pacific Northwest}

The rich cultures of the northwest coast of North America evolved institutions over hundreds of years to govern the interaction of their peoples with the natural world and the resources on which they subsisted. Institutions such as the "wilp" (house), the common bowl, and feasting assigned rights and responsibilities to houses and chiefs who regulated harvest, access, and distribution of benefits. In the wilp system, the members of a wilp were stewards of the resource and were responsible for respecting and conserving it for the good of all, including future generations. Members of the wilp were assigned roles in the allocation, harvesting, and preserving of different territories and natural resources (Raunet 1996; Nyce et al. personal communications). Until nearly the end of the 19th Century, First Nations in British Columbia were left to regulate their resource-based culture and economy with little or no interference from settlers or their governments (Harris 2001, p. 76).

In the late 19th and early 20th century as canneries took hold along the coast, most of the suppliers and the cannery workers were First Nations people who flocked to the canneries for seasonal work. First Nations men did the fishing and supplied their harvest to the canneries and First Nations women worked in the canneries canning the fish. Gradually, however, First Nations fishers and cannery workers began to lose control over the resource and over the institutions they had created for harvesting, conservation and distribution. The Dominion government began to regulate the fishery, with the result that First Nations were confined to "food fish" and were largely shut out of commercial fishing through discriminatory licensing. Later many traditional fishing practices and technologies (such as river weirs, traps and nets) were also made illegal through the Barricade Act of 1905. Earlier legislation (1885) banned the potlatch or feasting system and thus undermined not only the right to the fisheries but the traditional institutions that had historically governed them. The "potlatch" or feasting system was the basis of governance of most First Nations in the Pacific Northwest. Banning the potlatch meant banning the institutions that governed all of the life of the nation - that conferred legitimacy, assigned rights and responsibilities for territories and resources, ensured sharing of benefits and governed access, harvesting and conservation. Many First Nations people were jailed, fined, and persecuted and eventually alienated from their relationship to the resource and the natural world, thus beginning the process of devaluing traditional knowledge in resource management and laying the ground for continuing bitter conflicts among local and national regimes. Residential schools completed the process of alienating children 
from the knowledge of their ancestors and from traditional subsistence activities (Raunet 1996; Bracken 1997; Harris 2001). National institutions and more recently international environmental agreements have proved to be another force disenfranchising, disempowering and alienating indigenous people from the marine resource. The EEZ, for instance represents the enclosure of the commons in favour of one level in the governance system (the federal level) at the expense of other levels. In the case of First Nations, this is particularly damaging in view of the war over resources that has characterized much of the history of relationships between First Nations and government in Canada.

Newell and Ommer characterize this conflict as follows:

"The widening of the resource 'management world' from the community to the state (provincial and national) brought growing difficulties to small-scale community-ordered fisheries, which is perhaps not surprising, given the difficulties involved in matching the 'macro' state view with detailed ecological knowledge, which must be built from the grassroots up ..." (Newell and Ommer 1999, p. 3).

It may be argued that this trend is only recently being combated by the co-management arrangements negotiated with individual nations, including the Haida, Nisga'a and Gitksan, among others. Reluctant cooperation in co-management among former bitter adversaries is leading to joint management of fisheries and other resources throughout the Northwest. The agreement between Canada and the Haida Nation to manage Gwaii Haanas as a national park exemplifies the difficulties of melding two knowledge systems and two institutions. The agreement is written on two sides of the paper, with the Haida wording and understanding on one side and the Government of Canada wording on the other side. This acknowledges feelings that it is impossible to translate concepts of stewardship and management from one knowledge system to the other, from one language to anther. Haida writers, Miles Richardson and Bill Green summarize the view that led the Haida to the co-management table:

"Our relationship to the resources of Haida Gwaii cannot be managed by governments of another culture with a different set of values. This perhaps the most important reason for co-management-to provide a means for different cultures with conflicting values to share in a resource. Management of fisheries resources by one culture results in the almost complete loss of the ability of the resources to provide for the values of another culture" (Richardson and Green 1989, p. 259).

The struggle to regain rights, including rights to the fisheries is now playing itself out in the courts and in treaty negotiations taking place with many of the First Nations of British Columbia. The rights argument and its implications for environment and resources is summarized in the following statement by the Gitksan and Wet'suwet'en Chiefs who were plaintiffs in the Delgamuukw case:

"not only are we seeking recognition of title to the territories, but we are further seeking recognition of the jurisdiction of our people over their own lands... For us the ownership of 
territory, is a marriage of the chief and the land. Each Chief has an ancestor who encountered and acknowledged the life of the land. From such encounters come power. The land, the plants, the animals and the people all have spirit, they all must be shown respect. That is the basis of our law... Officials who are not accountable to this land, its laws or its owners, have attempted to displace our laws with legislation and regulations... The Gitksan and Wet'suwet'en, in asserting their rights of ownership and jurisdiction over their territory, are affirming the foundations upon which their civilizations are based and have been based for over 5000 years... We, the Chiefs, must have our authority recognized in order to exercise our responsibility to protect the land for the future and to conserve resources." (Gisday Wa and Delgam Uukw 1989).

A series of court cases has provided the legal basis for territorial rights and for new institutional arrangement governing First Nations fisheries in British Columbia. Many British Columbia First Nations never concluded treaties. They were allocated small reserves on the understanding that their fisheries would be protected. However, no First Nations fishing rights were recognized outside the reserves. First Nations fishers who were subject to the federal Department of Fisheries and Oceans (DFO) regulations, flaunted the law by fishing outside reserves and were zealously prosecuted for doing so. International Treaties such as the Canada/US Pacific Salmon Treaty reinforced and supported DFO regulations governing gear, timing and place restrictions which severely restricted First Nations fishing. Particularly damaging to First Nations fisheries was the power of the DFO to allocate salmon to other user groups before they reached the rivers (where most of the First Nations fishing takes place). The Calder, Sparrow, and Delgam Uukw court cases have succeeded in having First Nations rights to fish and other resources legally recognized. In his ruling on the Calder case Justice Hall wrote in 1973 that aboriginal title was a "right to occupy the lands and to enjoy the fruits of the soil, the forest and of the rivers and streams" (Notzke 1994, p. 46). In the Sparrow case, (1986) the court ruled that First Nations people have an unextinguished right to fish for food and native fishing should be given priority over other users rights, subject only to federal authority to ensure conservation of stocks (Notzke 1994, p. 46). In 1984 what has subsequently become known as the Delgam Uukw case began with the suit filed in a British Columbia court by 51 Hereditary Chiefs to force the Province to recognize Gitksan and Wet'suwet'en title to their traditional territories. One significant aspect of this case was the evidence presented by the Gitksan and Wet'suwet'en Chiefs about their historical knowledge, relationship and governance of the land and territories. First Nations had never before offered their own evidence to the court. After defeat for the Chiefs in the lower court, the British Columbia Court of Appeals ruled that the Gitksan and Wet'suwet'en did not have ownership but did have some non-exclusive rights within part of the territory. Thirteen years after the case began, in a landmark ruling in 1997, the Supreme Court of Canada interpreted Section 35 of the Canadian Constitution, which recognizes and affirms aboriginal rights. The court also recognized the role of traditional knowledge and oral history as evidence in establishing rights of First Nations people to land and resources. The long history of 
conflict has taken its toll on First Nations institutions and knowledge, but out of that conflict has come recognition of First Nations rights to the fishery and some creative institutional arrangement that might yet prove invaluable to fisheries and other environmental regimes at all levels. In many ways, the history of the Pacific Northwest fisheries is a history of mismanagement of the resource combined with the disenfranchisement of indigenous peoples, which is only very recently being reversed.

“Thus we arrive at the 1980's with a depleted resource, state managers striving to reduce the fishery, native fishers demanding aboriginal rights to greater allocations, sports fishers claiming special rights more in line with the increasing economic importance of their industry, and numerous disunified groups of commercial fishers mounting legal battles against these special claims on the specific grounds that the resource belongs to everyone." (Marchak 1987, p. 29).

Aboriginal people in the Pacific Northwest evolved a traditional management system based on extensive local knowledge which they traded with people up and down the entire coastal region - knowledge of fish distribution, behavior, and life cycles of the species, especially of salmon in the region. Fish and fishing were and are central to the life of First Nations people with profound socio-cultural, spiritual and economic significance. Marine resources, and especially salmon, are the very essence of the social fabric, and provide the basis for social, economic, political and territorial organization. Then as now, life, art and culture, technology, and transportation and trade routes revolved around fishing. The Nations' ethic, world-view, and spiritual and cultural practices were based largely on marine resources. Methods of monitoring, harvesting, assigning rights and responsibilities, sharing and distributing, trading, all focused on maintaining the human/fish and the human/natural world relationship. In the next section, I concentrate on the Nisga'a initiatives to rebuild institutions based on their traditional knowledge and to contribute that knowledge to their partners in fisheries management in the Pacific Northwest.

\section{Nisga'a Environmental Institutions}

The Nass (Lisims) river is the heart of the Nisga'a Nation. It flows through lava beds created by the massive and catastrophic eruption of a volcano which was seen as punishment for an incident of disrespect for a salmon by two young boys (oftrepeated personal communication). The resources of the river and the region have supported a complex and rich culture for centuries. Since the creation of the colony of British Columbia in 1858 the people of the Nass river have come into conflict with the new regimes imposed upon them. In 1887, the Nisga'a created a committee to bring the land question to the attention of the Provincial and Dominion Governments. For over a hundred years, they petitioned these governments to recognize Nisga'a claims to territory and natural resources of the region. Finally, on August 4, 1998, the Nisga'a Final Agreement was initialized by the Nisga'a, Canada, and British Columbia. The agreement came into effect on May 11, 2000, with a ceremony 
and the opening of the new Nisga'a Legislature, Wilp Si'ayuukhl Nisga'a. In preparation for this momentous event the Nisga'a people and their leaders had been developing institutions for self-government for many years. They were ready. These institutions were based on traditional institutions, knowledge and culture as codified and passed on in the Ayuukhl Nisga'a, the traditional laws and practice. Governance now consists of the Legislature, made up of Chief Councilors and Councilors elected by the residents of the four villages and each urban local, the Council of Elders who provide interpretation of the Ayuukhl and guidance to the government and the Nisga'a Lisims Government, the administrative body. The Nisga'a are very conscious of the need to preserve their traditional knowledge and apply it to all aspects of life for the approximately 5500 residents of the valley as well as Nisga'a residing outside of the Nass Valley. To do this they are deliberately combining traditional knowledge and institutions with new knowledge and in partnerships with outside institutions and with governments and industry.

To implement the agreement, an implementation committee was created with the governments of Canada and British Columbia. Under the agreement the Nisga'a Nation owns approximately 2000 square kilometers of Nisga'a Lands in fee simple and the right to harvest fish in the Nass Area (26,838 square kilometers) and harvest wildlife in the Nass Wildlife Area (16,101 square kilometers). In the process of "Nisga'anizing" fisheries and other resource regimes, they have retained traditional institutions such as the Wilp or house system of assigning rights and responsibilities for territories, the common bowl (symbolic of fair distribution of benefits to all Nisga'a), feasting as a source of leadership legitimacy, and traditional technologies, and blended them with other sources of knowledge such as those of the DFO scientists. In their co-management fisheries regime, Nisga'a Fisheries ensured their equal partnership by taking control of data generation using traditional technologies such as fish wheels for stock assessments and monitoring that produced data of much higher quality and more accurate predictions than had been previously available. Because traditional fisheries management had always been based on a total ecosystem approach, they were also very well placed to contribute conservation, habitat, and long term planning expertise to the partnership. The Joint Fisheries Management Committee, established by the Final Agreement, and the Technical Fisheries Group with representatives from the Federal Government (DFO) the Province and the Nisga'a, are responsible for the cooperative planning and conduct of Nisga'a Fisheries. Because the Nisga'a have trained technicians and have demonstrated superior knowledge of the resource, they are able to implement their Fishing Plan in their own terms. This has earned them a seat at international fisheries tables.

The results of the joint analysis produced a common international approach for sockeye assessment and counting. In the area of conservation and environmental protection, the Nisga'a Lisims Fisheries Trust was developed to ensure "a healthy productive, aquatic ecosystem for the benefit of present and future generations of all peoples" (Annual Report 2002, 2). For many years before the signing of the Final Agreement, the Nisga'a had developed co-management arrangements such as the 
Joint Park Management committee of the Nisga'a Nation and British Columbia to manage the Nisga'a Memorial Lava Bed Park (Anhluut'ukwsim Laxmihl Angwinga'asanskwhl Nisga'a). Similar co-management arrangements have been developed for forestry and wildlife management. The Nisga'a participants generally feel satisfied that they have succeed in having their values, knowledge, and culture prevail in the operation of these arrangements ( $\mathrm{H}$. Nyce, personal communication). It is clear that the Nisga'a success in co-management derives in large part from the legal recognition of aboriginal rights, their successful negotiation of the agreement with Canada and British Columbia, and their clarity of goals with regard to enshrining traditional knowledge and culture in natural resource management regimes. Other ways in which the Nisga'a have broken new institutional ground and preserved their traditional knowledge and institutions are in their recognition of the importance of language and education. They recognized the importance of education in institutionalizing a different way of knowing and supporting the language and culture that embodies the Nisga'a relationship with the earth and with each other. In 1994, in cooperation with the University of Northern British Columbia, the Nisga'a created their own institution for post-secondary education, Wilp Wilxo'oskwhl Nisga'a or the Nisga'a House of Wisdom. The Nisga'a also developed their own Health Board, School District, and Child and Family Services. While it is too early to judge the success of many of these initiatives, the Nisga'a appear to have vigorously applied their traditional knowledge to the development of new institutions and the revitalization of old institutions and have contributed that knowledge to environmental problem solving and policy with non-Nisga'a partners at various levels of governance. They thus provide some insights and lessons for institutional design and development.

\section{Conclusions}

Nisga'a traditional institutions have proven to be extremely resilient over time- a very long time. The wilp, or house system, the common bowl and feasting, while being forced underground for much of the first half of the 20th century, have been revived and survive to the present. Today they form the basis of the Nisga'a governance system recreated with the treaty. These institutions have not, however, remained rigidly the same but have adapted to changing circumstances and as they came into contact and conflict with other institutions at various levels. We can learn much about institutions and institutional change and effectiveness from investigating the development of these traditional institutions, the way in which they incorporate traditional knowledge and the way they promote knowledge change in their own institutions and in the institutions with whom they come into contact, conflict and cooperation. This paper ends with more questions than answers and reflects a very large research agenda. To return, however, to the questions listed in my introduction: does knowledge affect institutions? Yes - institutions are built upon and reflect the knowledge base, the shared beliefs, ideas and accumulated knowledge of their 
designers and those who participate in them. This becomes much clearer when one compares local traditional institutions with institutions at other levels which incorporate not only western science, but prevailing ideas and models within science. How does institutional interplay affect knowledge? Institutions interacting and coming into conflict with other institutions at the same or different levels of governance can affect knowledge and knowledge systems in a variety of ways and through a variety of mechanisms. They can privilege some knowledge forms and claims over others. They can do that simply by privileging one level of governance over another, by controlling data collection, by restricting the methods used to gather and disseminate information, by controlling research agendas, and by subscribing to one paradigm, technology, world-view, or idea, and having the power to impose that view upon those who may not subscribe to it.

The Nisga'a have shown that traditional institutions and knowledge systems can affect the knowledge systems of the dominant culture by holding and demonstrating superior knowledge of the ecosystem, or by embodying an approach (such as a traditional form of ecosystem management) that reveals itself to be more effective in addressing shared concerns over natural resource and environmental management.

Researchers have been concerned with the ways in which science finds its way into policy. In our research agenda we are also beginning to ask how other ways of knowing can find their way into environmental decision-making and policy at different levels of governance, not just the local level. We are left with the questions: How can our global environmental institutions reflect and incorporate the values and traditions of communities that we rely upon to enforce these arrangements? How can we design institutions that are open to changing ideas and other ways of knowing? This case reveals that knowledge and institutions impact one another not through simple mechanisms of cause and effect. There exist intricate interrelationships between knowledge systems and institutions, each shaping and changing the other. Future research attempting to provide a basis for improved institutional design and performance would do well to focus on all aspects and phases of that relationship.

\section{Acknowledgements}

I should like to thank the Nations and First Peoples in Northwest British Columbia for their hospitality, knowledge and wisdom. I thank also my colleagues in IDGEC and in particular Virginia Walsh whose passion for the idea of knowledge and institutions as a research focus inspired us all.

\section{References}

Balick, M. J. and P. A. Cox (1997), Plants. People, and Culture: The Science of Ethnobotany, New York, NY: Scientific American Library.

Battiste, M. and J. Y. Henderson (Sa'ke'j) (2000), Protecting Indigenous Knowledge and Heritage: A Global Challenge. Saskatoon, SK, Canada: Purich Publishing Ltd. 
Battiste, M., ed (2000), Reclaiming Indigenous Voice and Vision. Vancouver, BC: UBC Press.

Beckley, T. (1998), 'The nestedness of forest dependence: A conceptual framework and empirical exploration', Society and Natural Resources 11(2), 101-120.

Berkes, F., ed. (1989), Common Property Resources. London UK: Belhaven Press.

Berkes, F. et al. (1991), 'Co-management: The evolution in theory and practice of the joint administration of living resources', Alternatives 18(2), 12-18.

Berkes, F. (1994), 'Co-management: Bridging the two solitudes', Northern Perspectives 22(2-3), 18-20.

Berkes, F. (1999), Sacred Ecology: Traditional Knowledge and Resource Management. Philadelphia, PA: Taylor and Francis.

Borrini-Feyerabend, G., et al. (2000) Co-management of Natural Resources, Gland, Switzerland: IUCN.

Bracken, C. (1997), The Potlatch Papers, University of Chicago Press, Chicago, IL.

Brush, S. B. and D. Stabinsky, eds. (1996), Valuing Local Knowledge. Washington, DC: Island Press.

Calder, F. (1993). Foreword to Nisga'a: People of the Nass River. Vancouver. BC. Douglas and McIntyre.

Campbell, T. (1996), 'Comanangement of Aboriginal Resources', Information North 22(1).

Collins-Chobanain, S. (2000), 'Beyond Sax and Welfare Interests: A Case for Environmental Rights', Environmental Ethics 22, 133-148.

Christensen, B. (1995), Too Good To Be True: Alcan's Kemano Completion Project. Prince George, BC: Talonbooks, Ltd.

Gisday Wa and Delgam Uukw (1989), The Spirit in the Land: Statements of the Gitksam and Wet'suwet'en Hereditary Chiefs in the Supreme Court of British Columbia. 1987-1990. Reflections, Gabriola, BC.

Glavin, T. (2000), The Last Great Sea: A Voyage through the Human and Natural History of the North Pacific Ocean. Vancouver, BC: Douglas and McIntyre.

Goble, D. and P. Hirt (1999), Northwest Lands, Northwest Peoples: Readings in Environmental History. Seattle, WA: University of Washington Press.

Goulet, J. (1998), Ways of Knowing: Experience, Knowledge and Power Among the Dene Tha. Vancouver, BC: UBC Press.

Grinde, D., et al. (1995), Ecocide of Native America: Environmental Destruction of Indian Lands and Peoples. Santa Fe NM: Clear Light Publishers.

Harris, D. (2001), Fish, Law, and Colonialism: The Legal Capture of Salmon in British Columbia. Toronto, ON: University of Toronto Press.

Hester, L., et al. (2000), 'Indigenous Worlds and Callicott's Land Ethic', Environmental Ethics 22, 273-290.

Krech, S. (1999), The Ecological Indian: Myth and History. New York, NY: W.W. Norton and Co.

Mainville, R. (2001), An Overview of Aboriginal Treaty Rights and Compensation for their Breach. Saskatoon, SK, Canada: Purich Publishing.

Marchak, P., et al, eds. (1987), Uncommon Property: the Fishing and Fish Processing Industries in British Columbia. Methuen, Toronto, ON.

Nakashima, D.J., (1991), 'The Ecological Knowledge of Belcher Island Inuit: A traditional basis for contemporary wildlife co-management' Ph.D. Thesis Montreal, QC McGill University.

Nazarea, V., ed. (1999), Ethnoecology: Situated Knowledge/Located Lives. Tucson, Arizona: University of Arizona Press.

Newell, D. and R. Ommer (1999), Fishing Places, Fishing People: Traditions and Issues in Canadian Small Scale Fisheries. Toronto, ON, Canada: University of Toronto Press. 
Notzke, C. (1994), Aboriginal Peoples and Natural Resources in Canada. North York, ON: Captus Press.

Osherenko, G. (1998), 'Can co-management save Arctic wildlife?' Environment 30(6), 6-13, $29-34$.

Osherenko, G. (2001), 'Indigenous Rights in Russia: Is Title to Land Essential for cultural Survival?' The Georgetown International Environmental Law Review XIII, 3, 695733.

Ostrom, E. (1990), Governing the Commons. Cambridge UK: Cambridge University Press.

Pinkerton, E., ed. (1989), Co-operative Management of Local fisheries: New Directions for Improved Management and community Development. Vancouver, BC: UBC Press.

Pinkerton, E. (1999), 'Factors in Overcoming Barriers to Implementing Co-management in British Columbia Salmon Fisheries', Conservation Ecolog 3(2), 1-18.

Pinkerton, E.W. and M. Weinstein, (1995). Fisheries that Work, Sustainability through Community Based Management, Vancouver, BC: David Suzuki Foundation.

Posey, D. and G. Dutfield, (1996), Beyond Intellectual Property: Toward Traditional Resource Rights for Indigenous Peoples and Local Communities, Ottawa ON: International Development Research Centre (IDRC).

Prystupa, M.V. (1998), Barriers and strategies to the development of co-management regimes in New Zealand: The case of Te Waihora. Human Organization 57(2) 134 144.

Sax, J. (1990), 'The Search for Environmental Rights,' Journal of Land Use and Environmental Law 6, 94-103.

Raunet, D. (1996), Without Surrender. Without Consent: A History of the Nisga' a Land Claims. Vancouver, BC: Douglas and McIntyre.

Shkilnyk, A. (1985), A Poison Stronger Than Love: The Destruction of an Ojibwa Community. New Haven, CT: Yale University Press.

Singleton, S. (1998), Constructing Cooperation: the Evolution of Institutions of Co-management, Ann Arbor, MI, University of Michigan Press.

Slade, H. (1998), 'What Delgamuukw Actually Said', in J. McDonald(ed.), We're All Here To Stay: Forum on the Implications of the Delgamuukw Decision for Northern British Columbia. Prince George, BC, Canada: UNBC Press.

Steelman, T. and R. Wallace (2001), 'Property rights and Property wrongs: Why Context matters in fisheries management', Policy Sciences 34, 357-379.

Stevens, S. (1997), Conservation Through Cultural Survival. Island Press, Washington DC.

Tennant, P. (1999), Aboriginal Peoples and Politics: The Indian Land Question in British Columbia, 1849-1989. Vancouver, BC: UBC Press.

Walsh, V. (2000), 'Background Knowledge', Background Knowledge in World Politics. Unpublished manuscript.

Warren, P. (1998), Developing Participatory and Integrated Watershed Management. ROME, Italy, FAO Community Forestry Case Studie Series n.13.

Western, D. (1989), 'Conservation without parks: Wildlife in the rural landscape'. In D. Western and M. Pearl (eds.) Conservation for the twenty-first century. New York, NY: Oxford University Press.

Western, D and Wright, M. (1994), Natural Connections: Perspectives in Community-based Conservation. Washington, DC. Island Press.

White, R. (1995), The Organic Machine: The Remaking of the Columbia River. New York, NY: Hill and Wang.

Young, O. (2002), The Institutional Dimensions of Environmental Change: Fit, Interplay and Scale. Cambridge MA. MIT Press. 
Young, O., A. Agrawal, L. King, P. Sand, A. Underdal and M. Wasson (1999), Institutional Dimensions of Global Environmental Change. IDGEC Science Plan. IHDP, Bonn, Germany. Zerner, C., ed. (2000), People. Plants and Justice: The Politics of Nature Conservation. New York, NY: Columbia University Press. 